\title{
Psychological Backgrounds of Medically Compromised Patients and Its Implication in Dentistry: A Narrative Review
}

\author{
Yoshihiro Abiko ${ }^{1, *}$, Durga Paudel ${ }^{1}\left[\right.$, Hirofumi Matsuoka ${ }^{2}$, Mitsuru Moriya ${ }^{3}$ and Akira Toyofuku ${ }^{4}(\mathbb{D}$ \\ 1 Division of Oral Medicine and Pathology, Department of Human Biology and Pathophysiology, School of \\ Dentistry, Health Sciences University of Hokkaido, Hokkaido 061-0293, Japan; durga@hoku-iryo-u.ac.jp \\ 2 Division of Disease Control and Molecular Epidemiology, Department of Oral Growth and Development, \\ School of Dentistry, Health Sciences University of Hokkaido, Hokkaido 061-0293, Japan; \\ mazun@hoku-iryo-u.ac.jp \\ 3 Department of Psychosomatic Internal Medicine, Health Sciences University of Hokkaido Hospital, \\ Hokkaido 002-8072, Japan; mmoriya@hoku-iryo-u.ac.jp \\ 4 Department of Psychosomatic Dentistry, Graduate School of Medical and Dental Sciences, Tokyo Medical and \\ Dental University, Tokyo 113-8510, Japan; toyoompm@tmd.ac.jp \\ * Correspondence: yoshi-ab@hoku-iryo-u.ac.jp
}

Citation: Abiko, Y.; Paudel, D.

Matsuoka, H.; Moriya, M.; Toyofuku,

A. Psychological Backgrounds of

Medically Compromised Patients and Its Implication in Dentistry: A

Narrative Review. Int. J. Environ. Res. Public Health 2021, 18, 8792. https:// doi.org/10.3390/ijerph18168792

Academic Editor: Daisuke Ekuni

Received: 5 July 2021

Accepted: 18 August 2021

Published: 20 August 2021

Publisher's Note: MDPI stays neutral with regard to jurisdictional claims in published maps and institutional affiliations.

Copyright: (C) 2021 by the authors Licensee MDPI, Basel, Switzerland This article is an open access article distributed under the terms and conditions of the Creative Commons Attribution (CC BY) license (https:// creativecommons.org/licenses/by/ $4.0 /)$

\begin{abstract}
The number of medically compromised dental patients is increasing every year with the increase in the super-aged population. Many of these patients have underlying psychiatric problems and diseases, which need to be recognized by dental professionals for better treatment outcomes. The aim of this narrative review article is to summarize the psychological and psychiatric backgrounds of medically compromised patients who are frequently visited and taken care of by dentists using findings from recent systematic reviews and meta-analyses. Anxiety and symptoms of depression, post-traumatic stress disorders, panic disorders, poor cognitive functions, and poor quality of life were some of the common psychological backgrounds in medically compromised patients. Additionally, the consequences of these psychological problems and the considerations that need to be taken by the dentist while treating these patients have been discussed. Dental professionals should be aware of and recognize the different psychological backgrounds of medically compromised dental patients in order to provide appropriate dental treatment and to prevent oral conditions from worsening.
\end{abstract}

Keywords: anxiety; dental; depression; medically compromised patients; psychology

\section{Introduction}

The number of medically compromised patients is growing with the advance in the super-aged society in developed countries [1]. These patients need to be visited by a dentist more often with each progressing year. There are well established guidelines for how dentists see medically compromised patients for dental treatment [2]. Medically compromised patients may require regular prescriptions for their diseases or may experience an event that can interfere with their daily life. Many of these patients often have underlying psychological problems [3-10]. Dentists generally focus on dental problems, and the psychological backgrounds of these patients might often be neglected. The patient's motivation and their self-efficacy, which can be affected by their psychology, are important for the prevention and treatment of dental diseases.

The aim of this review is to summarize the psychological backgrounds of commonly encountered medically compromised conditions in dental patients. Previous studies have shown that cardiovascular diseases such as hypertension and heart disease as well as diabetes are among the five most prevalent medically compromised conditions in dental patients [11]. Renal diseases have high global prevalence, occurring in nearly $10 \%$ of the population [12]. Additionally, connective tissue disease has a prevalence ranging from 
5-30\% after 65 years of age [13]. Based on these findings and our clinical experience, we selected four medically compromised conditions; diabetes, cardiovascular disease, renal disease, and connective tissue disease and reviewed the psychological status of the patients. Various psychological backgrounds in these diseases are discussed with reference to findings from recent systematic reviews and meta-analyses. The consequences of psychological status and the considerations that need to be taken by the dentist while treating these patients have also been discussed in this review.

\section{Materials and Methods}

An electronic search was made on PubMed using the following search terms for each of four diseases: (diabetes) AND (psychology), (cardiovascular disease) AND (psychology), (renal disease) AND (psychology), (connective tissue disease) AND (psychology). Articles in English and that had been published within the last 5 years were included (March 2015March 2020). The studies were limited to systematic reviews and meta-analyses (Details in Supplementary Materials File S1). These articles formed the basis to show the psychological status of medically compromised patients. A few manually searched articles were also included in the review to discuss the implications of psychological background in dental treatment.

\section{Results and Discussion}

\subsection{Diabetes}

Diabetes is one of the four main non-communicable diseases (cardiovascular diseases, cancer, chronic respiratory diseases, and diabetes) and has a global prevalence of $8.5 \%$ among adults aged 18 years of age and older [14]. Some of the oral manifestations of diabetes include periodontal diseases, dental caries, candidiasis, burning sensation, altered taste, glossitis, and dry mouth [15]. The relationship between periodontal disease and diabetes is known to be bidirectional [16]. Diabetic patients have a high risk of periodontal diseases; the treatment of periodontal diseases in these patients may lead to a decrease in their blood glucose level [16].

Psychological approaches are often used in diabetic patients because they often suffer from psychological problems [17]. The psychological problems in diabetic patients might be due to diabetic distress [18], which is an emotional response to the burdens of living with diabetes and the self-care necessary to manage the condition. Diabetes-related distress has been reported in $36 \%$ of patients with type 2 diabetes [3]. Table 1 illustrates various psychological backgrounds of patients with diabetes [3,4,18-31]. The major psychological condition in diabetes includes depression and anxiety symptoms $[4,26]$. The pooled prevalence of depressive and anxiety symptoms in type 1 diabetic youth was shown to be $30 \%$ and $32 \%$, respectively [32]. A large cohort study showed that the prevalence of major depression in diabetic patients was twice that in healthy individuals [33]. Moreover, diabetic patients showed poor cognitive performance [19-21,31] and may have a higher risk of dementia [34]. Severe hypoglycemia in type 2 diabetes was associated with increased fear of hypoglycemia, decreased emotional well-being and health status, and a diabetes-specific quality of life $[35,36]$.

Table 1. Psychological background of patients with diabetes.

References

A. Poor quality of life

Depression, anxiety, and worry in diabetes is associated with poor quality of life [OR $=3.0(95 \% \mathrm{CI}$ : 1.135-7.948)]

B. Diabetes as a risk factor for psychological problems 
Table 1. Cont.

\begin{tabular}{|c|c|c|}
\hline & & References \\
\hline & Diabetic distress is present in about one-third of type 1 and type 2 diabetes mellitus patients & {$[3,18]$} \\
\hline & Depression, anxiety, low quality of life, and poor sleep are associated with painful diabetic neuropathy & [21] \\
\hline \multirow[t]{3}{*}{ C. } & Diabetes with depression leading to other complications & \\
\hline & Patients with diabetes and depression have poorer cognitive function compared to those with diabetes alone & [22] \\
\hline & $\begin{array}{l}\text { Patients with diabetes and depression have an increased risk of microvascular (retinopathy, neuropathy) } \\
((\mathrm{HR}=1.38 \text { (95\% CI: } 1.30-1.47)) \text { and macrovascular complications (stroke, angina, cardiovascular diseases) } \\
((\mathrm{HR}=1.33 \text { (95\% CI: } 1.25-1.41))\end{array}$ & [23] \\
\hline \multirow[t]{2}{*}{$D}$. & Diabetes as a risk factor for suicide & \\
\hline & Patients with diabetes have an increased risk of suicide ( $R R=1.56 ;(95 \%$ CI: $1.29-1.89))$ & [24] \\
\hline \multirow[t]{2}{*}{ E. } & Poor cognition & \\
\hline & $\begin{array}{l}\text { Diabetes in children and adults is associated with cognitive dysfunction such as lowered intelligence, } \\
\text { diminished attention, and slowing of psychomotor speed }\end{array}$ & {$[20,25,27,28]$} \\
\hline F. & Anxiety/Stress as a risk factor for diabetes & \\
\hline & Anxiety might be a risk factor for diabetes (OR = 1.47 (95\% CI: $1.23-1.75)$ ) & [29] \\
\hline & Women are associated with work-related stress and risk of diabetes $(\mathrm{RR}=1.22(95 \% \mathrm{CI}: 1.01-1.46))$ & [30] \\
\hline & $\begin{array}{l}\text { Workplace bullying victims had } 1.46 \text { times higher risk of developing diabetes compared to those who had } \\
\text { not experienced workplace bullying (HR = 1.46 (95\% CI: 1.23-1.74)) }\end{array}$ & [31] \\
\hline
\end{tabular}

These psychological and psychiatric problems may complicate diabetic-related cardiovascular diseases, blood glucose level, and may worsen the quality of life [37]. Depression in patients with diabetes has been associated with increased risks for micro- and macrovascular complications and neuropathy $[29,38]$. Microvascular complications include retinopathy, neuropathy, and diabetic foot, whereas macrovascular complications include stroke, angina, cardiovascular diseases, and myocardial infarction. Furthermore, anxiety and stress may worsen the diabetic condition in these patients.

The effect of different types of psychological and psychiatric problems, including depressive conditions, may be seen during oral health and treatment. Depressive conditions in diabetes often decrease self-efficacy and the capacity for self-management [39], which might also lead to poor oral hygiene. Moreover, poor cognitive functions such as poor attention, slow psychomotor function, and poor processing speed in patients with diabetes compared to healthy individuals should be taken into consideration while planning dental treatment $[19,31]$. The increased risk of microvascular neuropathy in diabetic patients with depression should also be considered in dental treatment. Thus, dental professionals may need to recognize the psychological and psychiatric backgrounds of each diabetic patient in the dental setting.

\subsection{Cardiovascular Diseases}

Cardiovascular diseases are the number one cause of global death, constituting nearly one third of all global deaths [40]. Cardiovascular diseases include coronary heart disease, cerebrovascular disease, peripheral arterial disease, rheumatic heart disease, congenital heart disease, deep vein thrombosis, and pulmonary embolism. Acute events such as heart attack and stroke resulting from one or more cardiovascular diseases account for the majority of deaths and disabilities [40]. Dental professionals are generally cautious about underlying cardiovascular diseases during dental treatment. These patients need special care, mainly during oral surgical procedures and during medication administration. Blood pressure maintenance, hemorrhage prevention, and effects due to use of anticoagulants or anti-thrombin medications are often challenging during dental treatment in these patients [41]. 
Stress is a major exacerbation factor for hypertension, cardiac diseases, and arteriosclerosis [42,43]. Table 2 shows the psychological backgrounds of patients with cardiovascular diseases [5,6,42-53]. Anxiety and depression are major psychological factors in patients with cardiovascular diseases $[5,48,49]$. Furthermore, patients with cardiovascular diseases often have post-traumatic stress disorder (PTSD) induced by the event of a heart attack $[6,50]$ and may experience anticipatory anxiety, which could be linked to other types of anxiety and depression. A recent meta-analysis showed a random-effects pooled prevalence of $13.1 \%$ for anxiety disorders, $28.79 \%$ for probable clinically significant anxiety, and $55.5 \%$ for elevated symptoms of anxiety among patients with heart failure [48]. The prevalence of depressive symptoms in males and females with coronary heart diseases was $23.47 \%$ and $35.75 \%$, respectively, at the time of hospital admission [54]. The risk of developing depression in patients with coronary artery disease was 2.8 times higher than that in healthy individuals [55]. Patients with ischemic heart disease must practice self-care methods to prevent the occurrence of events, which can become a new stressor. These stresses in combination with anticipatory anxiety may be responsible for the high prevalence of anxiety and depression in patients with cardiovascular diseases.

Table 2. Psychological backgrounds of patients with cardiovascular diseases.

References

A. Anxiety and depression in cardiovascular patients

Prevalence of anxiety in heart failure: anxiety disorders (13.1\%), clinically significant anxiety (28.7\%), and elevated symptoms of anxiety $(55.5 \%)$

Prevalence of depression in peripheral arterial disease: $3 \%$ to $48 \%$ prevalence of depression in myocardial infarction: female (36\%), male ( $29 \%)$

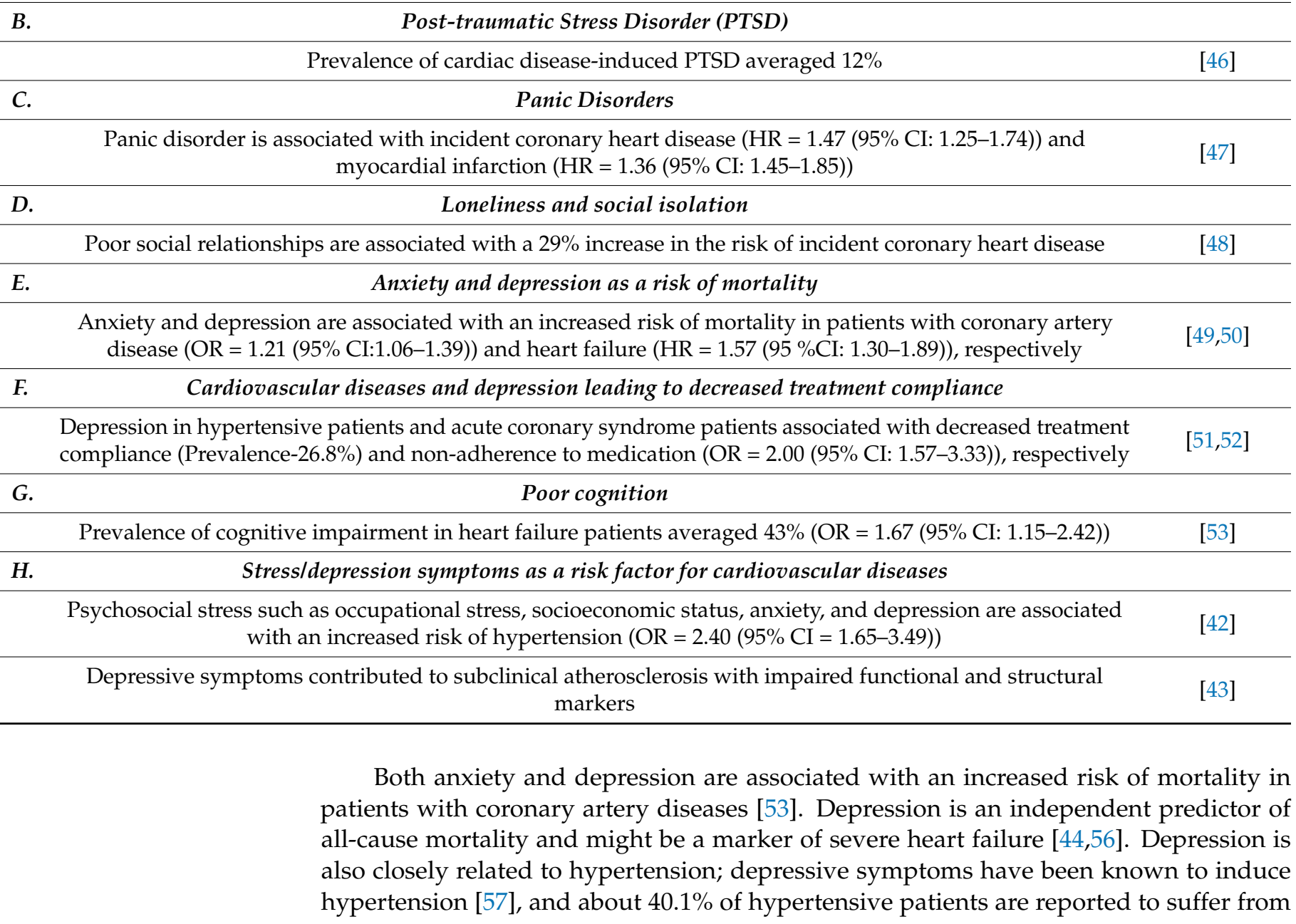


depression [58]. Hypertensive patients with depression have poor health status and a lower quality of life and demonstrate decreased treatment compliance [45]. Several review articles have indicated that cardiovascular diseases often induce psychological problems. Patients with arrhythmia frequently experience anxiety, whereas patients with paroxysmal atrial fibrillation often present with avoidant behavior due to fear of paroxysm [59]. Furthermore, patients with implantable cardiac defibrillators are fearful of electric shock [60].

Patients with cardiovascular diseases often experience several levels of anxiety and depression. Those suffering from anxiety and depression often have less distress tolerance, which may cause dental phobia [61]. Furthermore, stressful conditions such as dental treatments may worsen their psychological problems. Depression in cardiovascular disease is associated with decreased treatment compliance and non-adherence to medication, which may affect the prognosis of dental treatment $[45,46]$. Poor cognitive outcomes such as nonverbal reasoning, processing speed and attention, psychomotor abilities, and numeracy in patients with cardiovascular diseases may require consideration in dental treatment $[47,62]$.

\subsection{Renal Diseases}

Renal diseases are among significant contributors to morbidity and mortality from noncommunicable diseases globally [63]. Nation surveys in Australia, Norway, and the USA showed that at least $10 \%$ of the adult population have markers for kidney disease. A global prevalence of $9.1 \%$ has been shown for cases of all-stage chronic kidney diseases (CKD) [12]. Dental professionals commonly encounter renal patients during dental treatment and should be cautious of their tendency for hemorrhage and the increased susceptibility to infection in dialysis patients $[64,65]$. Additionally, certain drugs involved in renal metabolism have to be carefully prescribed for such patients [65].

CKD is characterized by a gradual loss of kidney function requiring frequent dialysis, which impairs the activities of daily living. Dialysis patients are at a significant increased risk for sarcopenia and frailty [66] and are under constant psychological stress. Many of these patients experience psychological and psychiatric problems, and the study of the psychological factors in these patients has been termed as "psychonephrology" [67]. The psychological backgrounds of patients with renal diseases are shown in Table 3 [7,8,68-75]. Dialysis patients without any psychiatric history often develop sleep disturbances, depression, anxiety, delirium, dementia, and restless leg syndrome [67]. Depression was reported as one of the most prevalent mental diseases in hemodialysis patients, and the depressive symptoms were found to be closely associated with malnutrition [7]. A previous study showed a pooled prevalence of $62 \%$ for depressive symptoms in patients undergoing hemodialysis [68]. The depressive symptoms in CKD patients might be due to these negative emotions and distress [69] as well as the malnutrition in those undergoing hemodialysis. Physical disorders such as uremia, hypercalcemia, and cerebrovascular damage, along with psychological stress, can also cause depressive symptom [76]. Furthermore, medications such as steroids, interferon, antihypertensive drugs, and anti-parkinsonism drugs can induce depression in CKD patients [77].

Table 3. Psychological backgrounds of patients with renal diseases.

References

A. Anxiety, Distress, and Depression

Depression is one of the most prevalent mental illnesses (ranging from 6-83.5\% among studies) in hemodialysis patients.

Chronic Kidney Disease (CKD) patients have negative emotions and distress. Disease severity and illness perception is associated with depression

Low albumin, high Interlukin-6, and high C-Reactive Protein are associated with the severity of depressive symptoms in chronic renal disease

Kidney transplant patients are exposed to a high risk of psychiatric disorders such as mental distress, behavioral and adaptation difficulties, cognitive impairments and depressive symptoms, sleep disorders, anxiety, and depression 
Table 3. Cont.

\begin{tabular}{|c|c|c|}
\hline & & References \\
\hline \multirow[t]{2}{*}{ B. } & Post-Traumatic Stress Disorder (PTSD) & \\
\hline & PTSD is common in patients with solid organ transplants, including renal transplant & [8] \\
\hline \multirow[t]{3}{*}{ C. } & Effect on cognition & \\
\hline & $\begin{array}{l}\text { Renal patients experienceeffects on orientation and attention, language, concept formation and reasoning, } \\
\text { executive function, memory, and global cognition. The cognitive impact might diminish the patient's ability } \\
\text { to make health care decisions }\end{array}$ & [72] \\
\hline & The pooled prevalence of cognitive impairment among peritoneal dialysis patients is $28.7 \%$ & [73] \\
\hline \multirow[t]{2}{*}{ D. } & Effect on quality of life & \\
\hline & Renal failure is associated with lower quality of life in young adults & [74] \\
\hline E. & Need for social support & \\
\hline & $\begin{array}{l}\text { A significant association between social support and treatment adherence is seen in patients with end-stage } \\
\text { renal disease. }\end{array}$ & [75] \\
\hline
\end{tabular}

The depression symptoms in dialysis patients may demonstrate decreased adherence to treatment, which affects oral health care. Studies have shown that social support from family and health care professionals is associated with treatment adherence in CKD patients [75]. The treatment adherence of patient is an important factor in successful dental treatment. Dialysis patients are at increased risk of developing dementia [67], which may present with an increased risk for physical frailty, including oral frailty [78]. CKD has a significant impact on cognition, which might diminish the ability of the patient to make health care decisions [72]; this factor should be considered during dental treatment. Thus, dental professionals must be aware of the psychological and psychiatric background of patients with renal diseases, particularly those undergoing dialysis, in a dental setting.

\subsection{Connective Tissue Diseases}

Connective tissue diseases refer to a group of heterogenous and immunologically mediated disorders such as rheumatoid arthritis, systemic lupus erythematosus, systemic sclerosis, and Sjogren's syndrome. The prevalence ranges from $5-30 \%$ after the age of 65 years [13]. Oral manifestations may appear during the early phases of these diseases, and dental professionals may need to identify, manage, and refer accordingly.

The oral symptoms in connective tissue diseases mainly manifest as xerostomia and aphthous stomatitis. Those patients with connective tissue diseases and who are taking steroids have an increased susceptibility to infections and are at a high risk for the progression of periodontal diseases and opportunistic infections such as candidiasis [79,80]. Moreover, patients with hyposalivation are prone to oral infections [81]. Chronic inflammation in patients with connective tissue diseases induces fatigue and stress, and these diseases may be involved in the development of psychiatric diseases caused by neuritis [82]

The psychological backgrounds of patients with connective tissue diseases are shown in Table 4 [9,83-91]. Fatigue associated with psychosocial factors, such as depression, pain, and sleep disorders, were the most prevalent symptom in patients with connective tissue diseases [84]. Each type of connective tissue disease is associated with a different type of psychological problem. Rheumatoid arthritis patients experience fatigue $[84,86]$ and poor cognitive function [90] and need to be treated for issues such as negative emotions, anxiety, and depression. Therapeutic interventions for immunological disorders improve both depression and the pathological condition in patients with rheumatoid arthritis, indicating that immunological disorders may be involved in causing depression in these patients [92]. Patients with systemic lupus erythematosus (SLE) frequently present with various types of psychiatric problems, such as impaired consciousness, anxiety disorders, cognitive disorders, mood disorders, and schizophrenia-like psychosis, which are collectively termed 
as neuropsychiatric SLE (NPSLE) [93,94]. Sjögren's syndrome, a collagen-related disease, affects the senses of smell and taste, sexual function, and quality of life [88]; Approximately $33.8 \%$ and $36.9 \%$ of patients with this syndrome were reported to experience anxiety and depression, respectively [95]. The odds ratio of depression in patients with Sjögren's syndrome, when compared to that of healthy individuals, was 5.32 [95]. Patients with connective tissue diseases who take steroid medications often have mood disorders and hallucinations, which is termed as "steroid psychosis" [96]. A high dose of steroids frequently induces this condition in patients, making it difficult for the clinician to ascertain the cause of the symptoms [97].

Table 4. Psychological backgrounds of patients with connective tissue diseases.

References

\begin{tabular}{|c|c|c|}
\hline & & References \\
\hline \multirow[t]{3}{*}{ A. } & Anxiety and depression & \\
\hline & $\begin{array}{c}\text { The depressive (6.7\% to 59\%) and anxiety symptoms (34\% to } 37 \%) \text { are prevalent in childhood-onset systemic } \\
\text { lupus erythematosus (SLE) }\end{array}$ & [9] \\
\hline & $\begin{array}{l}\text { Patients with rheumatoid arthritis are associated with an increased risk of anxiety OR }=1.20(95 \% \text { CI: } \\
\qquad 1.03-1.39)\end{array}$ & [83] \\
\hline \multirow[t]{4}{*}{ B. } & Fatigue in connective tissue diseases and its psychosocial factors & \\
\hline & Fatigue in SLE is associated with psychosocial factors (depression, pain, and sleep disorders) & [84] \\
\hline & $\begin{array}{l}\text { The dominant unpredictability of rheumatoid arthritis-related fatigue is experienced as a vicious circle } \\
\text { described in relation to its physical, cognitive, emotional, and social impact }\end{array}$ & [85] \\
\hline & Low mood is associated with increased fatigue in rheumatoid arthritis patients & [86] \\
\hline \multirow[t]{4}{*}{ C. } & Poor quality of life & \\
\hline & $\begin{array}{l}\text { SLE has a significant impact on the health-related quality of life (Mental component summary }=50.37(95 \% \\
\text { CI: } 47.78-52.87))\end{array}$ & [87] \\
\hline & $\begin{array}{l}\text { Primary Sjögren's syndrome has an impact on quality of life in female patients (mental component of the } \\
\text { quality of life }=-0.83(95 \% \mathrm{CI}:-1.27 \text { to }-0.40))\end{array}$ & [88] \\
\hline & $\begin{array}{l}\text { There is a significant association between the oropharyngeal manifestations of systemic sclerosis (assessed as } \\
\text { maximal mouth opening and mouth handicap in systemic sclerosis scale) and impaired quality of life }\end{array}$ & [89] \\
\hline \multirow[t]{2}{*}{ D. } & Poor cognitive function & \\
\hline & $\begin{array}{l}\text { A significant underperformance in cognitive function tests, mainly verbal functions, memory, and attention } \\
\text { in rheumatoid arthritis patients is observed when compared to controls }\end{array}$ & [90] \\
\hline$E$. & Suicide ideation and attempt & \\
\hline & $\begin{array}{l}\text { Rheumatic diseases patients have a high pooled prevalence of suicidal ideation }(26 \%) \text { and suicide attempts } \\
(12 \%) \text {. The prevalence of suicidal ideation and a suicidal attempts is higher in females than in males }\end{array}$ & [91] \\
\hline
\end{tabular}

Patients with connective tissue diseases may have complex psychiatric problems because both immunological disorders and psychological stress can induce psychiatric diseases. Patients with connective tissue diseases often experience fatigue, which is associated with psychosocial factors such as pain, depression, sleep disorders, and low mood [84-86]. These factors should be considered during dental treatment. Previous studies have shown a significant association between the oropharyngeal manifestations of systemic sclerosis (assessed as maximal mouth opening and mouth handicap in systemic sclerosis scale) and impaired quality of life [89]. These factors are particularly of a dentist's concern and should be considered during the dental treatment of these patients.

\section{Psychology and Its Implication in Dentistry}

The effect of various psychological backgrounds of patients with diabetes, cardiovascular diseases, renal diseases, and connective tissue diseases in dental treatment have been discussed in this article. The most common psychological states in those patients were anxiety, depression, post-traumatic stress disorders, panic disorders, poor cognitive 
functions, and poor quality of life. In general, psychological stress, anxiety, and depression have been linked to many oral mucosal diseases, such as burning mouth syndrome, lichen planus, and the recurrence aphthous stomatitis [98-100]. Psychological stresses have also been associated with periodontal diseases [101] and dental caries [102]. Negative human behavior such as low self-efficacy in adverse psychological conditions might worsen the oral environment [103]. A systematic review and meta-analysis studying the effect of psychological state on oral health showed that all of the psychiatric diagnoses were associated with increased dental caries and tooth loss on the mean number of decayed, missing, and filled teeth (DMFT) or surfaces (DMFS) scores (OR $=1.22 ; 95 \% \mathrm{CI}=1.14-1.30)$ [104]. The psychological states of medically compromised patients could therefore affect the oral health. The periodic monitoring of oral health and needful intervention at earlier stages of oral disease might be important.

The limitation of our study is that it is a narrative review and strict study selection criteria were not followed. The results of systematic reviews and meta-analyses were cited to discuss the possible psychological backgrounds of medically compromised patients. The studies highlighting the psychological status of dental patients with medically compromised conditions are very limited, and this topic needs to be further studied.

\section{Conclusions}

This review focused on the psychological and psychiatric backgrounds of medically compromised dental patients, i.e., those with diabetes, cardiovascular disease, renal disease, and connective tissue diseases. The psychological backgrounds of medically compromised patient are diverse. Dental professionals should be aware of and recognize these backgrounds in addition to the systemic conditions in order to provide the appropriate dental treatment and to prevent the oral conditions from worsening.

Supplementary Materials: The following are available online at https:/ / www.mdpi.com/article/10 .3390/ijerph18168792/s1, File S1: Search strategy.

Funding: This research received no external funding.

Institutional Review Board Statement: Not applicable.

Informed Consent Statement: Not applicable.

Data Availability Statement: Not applicable.

Conflicts of Interest: The authors declare no conflict of interest.

\section{References}

1. Lamster, I.B. Geriatric periodontology: How the need to care for the aging population can influence the future of the dental profession. Periodontol. 2000 2016, 72, 7-12. [CrossRef]

2. The ADA Practical Guide to Patients with Medical Conditions; Patton, L.L.; Glick, M. (Eds.) John Wiley \& Sons, Inc.: Hoboken, NJ, USA, 2015; ISBN 9781119121039.

3. Perrin, N.E.; Davies, M.J.; Robertson, N.; Snoek, F.J.; Khunti, K. The prevalence of diabetes-specific emotional distress in people with Type 2 diabetes: A systematic review and meta-analysis. Diabet. Med. 2017, 34, 1508-1520. [CrossRef] [PubMed]

4. Tong, A.; Wang, X.; Li, F.; Xu, F.; Li, Q.; Zhang, F. Risk of depressive symptoms associated with impaired glucose metabolism, newly diagnosed diabetes, and previously diagnosed diabetes: A meta-analysis of prospective cohort studies. Acta Diabetol. 2016, 53, 589-598. [CrossRef] [PubMed]

5. Doyle, F.; McGee, H.; Conroy, R.; Conradi, H.J.; Meijer, A.; Steeds, R.; Sato, H.; Stewart, D.E.; Parakh, K.; Carney, R.; et al. Systematic Review and Individual Patient Data Meta-Analysis of Sex Differences in Depression and Prognosis in Persons with Myocardial Infarction. Psychosom. Med. 2015, 77, 419-428. [CrossRef] [PubMed]

6. Akosile, W.; Colquhoun, D.; Young, R.; Lawford, B.; Voisey, J. The association between post-traumatic stress disorder and coronary artery disease: A meta-analysis. Australas. Psychiatry 2018, 26, 524-530. [CrossRef]

7. Gebrie, M.H.; Ford, J. Depressive symptoms and dietary non-adherence among end stage renal disease patients undergoing hemodialysis therapy: Systematic review. BMC Nephrol. 2019, 20, 429. [CrossRef]

8. Supelana, C.; Annunziato, R.A.; Kaplan, D.; Helcer, J.; Stuber, M.L.; Shemesh, E. PTSD in solid organ transplant recipients: Current understanding and future implications. Pediatr. Transplant. 2016, 20, 23-33. [CrossRef] 
9. Quilter, M.; Hiraki, L.; Korczak, D. Depressive and anxiety symptom prevalence in childhood-onset systemic lupus erythematosus: A systematic review. Lupus 2019, 28, 878-887. [CrossRef]

10. Matcham, F.; Rayner, L.; Steer, S.; Hotopf, M. The prevalence of depression in rheumatoid arthritis: A systematic review and meta-analysis. Rheumatology 2013, 52, 2136-2148. [CrossRef]

11. Dhanuthai, K.; Sappayatosok, K.; Bijaphala, P.; Kulvitit, S.; Sereerat, T. Prevalence of medically compromised conditions in dental patients. Med. Oral Patol. Oral Cir. Bucal. 2009, 14, E287-E291.

12. GBD Chronic Kidney Disease Collaboration. Global, regional, and national burden of chronic kidney disease, 1990-2017: A systematic analysis for the Global Burden of Disease Study 2017. Lancet 2020, 395, 709-733. [CrossRef]

13. Spagnolo, P.; Cordier, J.-F.; Cottin, V. Connective tissue diseases, multimorbidity and the ageing lung. Eur. Respir. J. 2016, 47, 1535-1558. [CrossRef]

14. World Health Organization. Diabetes. WHO Fact Sheets. 2020. Available online: https://www.who.int/news-room/fact-sheets/ detail/diabetes (accessed on 22 May 2021).

15. Albert, D.A.; Ward, A.; Allweiss, P.; Graves, D.T.; Knowler, W.C.; Kunzel, C.; Leibel, R.L.; Novak, K.F.; Oates, T.W.; Papapanou, P.N.; et al. Diabetes and oral disease: Implications for health professionals. Ann. N. Y. Acad. Sci. 2012, 1255, 1-15. [CrossRef] [PubMed]

16. Preshaw, P.M.; Alba, A.L.; Herrera, D.; Jepsen, S.; Konstantinidis, A.; Makrilakis, K.; Taylor, R. Periodontitis and diabetes: A two-way relationship. Diabetologia 2012, 55, 21-31. [CrossRef] [PubMed]

17. Price, H.C.; Ismail, K.; Allan, B.; Castro, E.; Dashora, U.; Dhatariya, K.; Flanagan, D.; George, S.; Gregory, R.; James, J.; et al. Royal College of Psychiatrists Liaison Faculty \& Joint British Diabetes Societies (JBDS): Guidelines for the management of diabetes in adults and children with psychiatric disorders in inpatient settings. Diabet. Med. 2018, 35, 997-1004. [CrossRef] [PubMed]

18. Hagger, V.; Hendrieckx, C.; Sturt, J.; Skinner, T.C.; Speight, J. Diabetes Distress Among Adolescents with Type 1 Diabetes: A Systematic Review. Curr. Diab. Rep. 2016, 16, 9. [CrossRef] [PubMed]

19. Chen, Y.; Liu, Z.; Yu, Y.; Yao, E.; Liu, X.; Liu, L. Effect of recurrent severe hypoglycemia on cognitive performance in adult patients with diabetes: A meta-analysis. Curr. Med. Sci. 2017, 37, 642-648. [CrossRef] [PubMed]

20. Niermeyer, M.A. Cognitive and gait decrements among non-demented older adults with Type 2 diabetes or hypertension: A systematic review. Clin. Neuropsychol. 2018, 32, 1256-1281. [CrossRef] [PubMed]

21. Li, W.; Huang, E.; Gao, S. Type 1 Diabetes Mellitus and Cognitive Impairments: A Systematic Review. J. Alzheimer's Dis. 2017, 57, 29-36. [CrossRef]

22. Smith, K.J.; Deschênes, S.S.; Schmitz, N. Investigating the longitudinal association between diabetes and anxiety: A systematic review and meta-analysis. Diabet. Med. 2018, 35, 677-693. [CrossRef]

23. Sui, H.; Sun, N.; Zhan, L.; Lu, X.; Chen, T.; Mao, X. Association between Work-Related Stress and Risk for Type 2 Diabetes: A Systematic Review and Meta-Analysis of Prospective Cohort Studies. PLoS ONE 2016, 11, e0159978. [CrossRef]

24. Xu, T.; Magnusson Hanson, L.L.; Lange, T.; Starkopf, L.; Westerlund, H.; Madsen, I.E.H.; Rugulies, R.; Pentti, J.; Stenholm, S.; Vahtera, J.; et al. Workplace bullying and violence as risk factors for type 2 diabetes: A multicohort study and meta-analysis. Diabetologia 2018, 61, 75-83. [CrossRef] [PubMed]

25. Jing, X.; Chen, J.; Dong, Y.; Han, D.; Zhao, H.; Wang, X.; Gao, F.; Li, C.; Cui, Z.; Liu, Y.; et al. Related factors of quality of life of type 2 diabetes patients: A systematic review and meta-analysis. Health Qual. Life Outcomes 2018, 16, 189. [CrossRef] [PubMed]

26. Amiri, S.; Behnezhad, S. Diabetes and anxiety symptoms: A systematic review and meta-analysis. Int. J. Psychiatry Med. 2019. [CrossRef] [PubMed]

27. Kioskli, K.; Scott, W.; Winkley, K.; Kylakos, S.; McCracken, L.M. Psychosocial Factors in Painful Diabetic Neuropathy: A Systematic Review of Treatment Trials and Survey Studies. Pain Med. 2019, 20, 1756-1773. [CrossRef] [PubMed]

28. Danna, S.M.; Graham, E.; Burns, R.J.; Deschênes, S.S.; Schmitz, N. Association between Depressive Symptoms and Cognitive Function in Persons with Diabetes Mellitus: A Systematic Review. PLoS ONE 2016, 11, e0160809. [CrossRef] [PubMed]

29. Nouwen, A.; Adriaanse, M.C.; Dam, K.; Iversen, M.M.; Viechtbauer, W.; Peyrot, M.; Caramlau, I.; Kokoszka, A.; Kanc, K.; Groot, M.; et al. Longitudinal associations between depression and diabetes complications: A systematic review and meta-analysis. Diabet. Med. 2019, 36, 1562-1572. [CrossRef] [PubMed]

30. Wang, B.; An, X.; Shi, X.; Zhang, J. Management of endocrine disease: Suicide risk in patients with diabetes: A systematic review and meta-analysis. Eur. J. Endocrinol. 2017, 177, R169-R181. [CrossRef]

31. He, J.; Ryder, A.G.; Li, S.; Liu, W.; Zhu, X. Glycemic extremes are related to cognitive dysfunction in children with type 1 diabetes: A meta-analysis. J. Diabetes Investig. 2018, 9, 1342-1353. [CrossRef]

32. Buchberger, B.; Huppertz, H.; Krabbe, L.; Lux, B.; Mattivi, J.T.; Siafarikas, A. Symptoms of depression and anxiety in youth with type 1 diabetes: A systematic review and meta-analysis. Psychoneuroendocrinology 2016, 70, 70-84. [CrossRef]

33. Mommersteeg, P.M.C.; Herr, R.; Pouwer, F.; Holt, R.I.G.; Loerbroks, A. The association between diabetes and an episode of depressive symptoms in the 2002 World Health Survey: An analysis of 231,797 individuals from 47 countries. Diabet. Med. 2013, 30, e208-e214. [CrossRef]

34. Heslop, P.; Blair, P.S.; Fleming, P.; Hoghton, M.; Marriott, A.; Russ, L. The Confidential Inquiry into premature deaths of people with intellectual disabilities in the UK: A population-based study. Lancet 2014, 383, 889-895. [CrossRef]

35. Hendrieckx, C.; Ivory, N.; Singh, H.; Frier, B.M.; Speight, J. Impact of severe hypoglycaemia on psychological outcomes in adults with Type 2 diabetes: A systematic review. Diabet. Med. 2019, 36, 1082-1091. [CrossRef] 
36. Vanstone, M.; Rewegan, A.; Brundisini, F.; Dejean, D.; Giacomini, M. Patient Perspectives on Quality of Life With Uncontrolled Type 1 Diabetes Mellitus: A Systematic Review and Qualitative Meta-synthesis. Ont. Health Technol. Assess. Ser. 2015, 15, 1-29.

37. Dalsgaard, E.-M.; Vestergaard, M.; Skriver, M.V.; Maindal, H.T.; Lauritzen, T.; Borch-Johnsen, K.; Witte, D.; Sandbaek, A. Psychological distress, cardiovascular complications and mortality among people with screen-detected type 2 diabetes: Follow-up of the ADDITION-Denmark trial. Diabetologia 2014, 57, 710-717. [CrossRef] [PubMed]

38. Bartoli, F.; Carrà, G.; Crocamo, C.; Carretta, D.; La Tegola, D.; Tabacchi, T.; Gamba, P.; Clerici, M. Association between depression and neuropathy in people with type 2 diabetes: A meta-analysis. Int. J. Geriatr. Psychiatry 2016, 31, 829-836. [CrossRef] [PubMed]

39. Lin, K.; Park, C.; Li, M.; Wang, X.; Li, X.; Li, W.; Quinn, L. Effects of depression, diabetes distress, diabetes self-efficacy, and diabetes self-management on glycemic control among Chinese population with type 2 diabetes mellitus. Diabetes Res. Clin. Pract. 2017, 131, 179-186. [CrossRef]

40. World Health Organization. Cardiovascular Disease. Fact Sheets. 2017. Available online: https://www.who.int/en/news-room/ fact-sheets/detail/cardiovascular-diseases-(cvds) (accessed on 22 May 2021).

41. Jowett, N.; Cabot, L. Patients with cardiac disease: Considerations for the dental practitioner. Br. Dent. J. 2000, 189, 297-302. [CrossRef]

42. Liu, M.-Y.; Li, N.; Li, W.A.; Khan, H. Association between psychosocial stress and hypertension: A systematic review and meta-analysis. Neurol. Res. 2017, 39, 573-580. [CrossRef] [PubMed]

43. Wu, Y.; Sun, D.; Wang, B.; Li, Y.; Ma, Y. The relationship of depressive symptoms and functional and structural markers of subclinical atherosclerosis: A systematic review and meta-analysis. Eur. J. Prev. Cardiol. 2018, 25, 706-716. [CrossRef] [PubMed]

44. Sokoreli, I.; de Vries, J.J.G.; Pauws, S.C.; Steyerberg, E.W. Depression and anxiety as predictors of mortality among heart failure patients: Systematic review and meta-analysis. Heart Fail. Rev. 2016, 21, 49-63. [CrossRef] [PubMed]

45. Li, Z.; Li, Y.; Chen, L.; Chen, P.; Hu, Y. Prevalence of Depression in Patients with Hypertension. Med. (Baltim.) 2015, 94, e1317. [CrossRef]

46. Crawshaw, J.; Auyeung, V.; Norton, S.; Weinman, J. Identifying psychosocial predictors of medication non-adherence following acute coronary syndrome: A systematic review and meta-analysis. J. Psychosom. Res. 2016, 90, 10-32. [CrossRef] [PubMed]

47. Cannon, J.A.; Moffitt, P.; Perez-Moreno, A.C.; Walters, M.R.; Broomfield, N.M.; McMurray, J.J.V.; Quinn, T.J. Cognitive Impairment and Heart Failure: Systematic Review and Meta-Analysis. J. Card. Fail. 2017, 23, 464-475. [CrossRef] [PubMed]

48. Easton, K.; Coventry, P.; Lovell, K.; Carter, L.-A.; Deaton, C. Prevalence and Measurement of Anxiety in Samples of Patients with Heart Failure. J. Cardiovasc. Nurs. 2016, 31, 367-379. [CrossRef] [PubMed]

49. Brostow, D.P.; Petrik, M.L.; Starosta, A.J.; Waldo, S.W. Depression in patients with peripheral arterial disease: A systematic review. Eur. J. Cardiovasc. Nurs. 2017, 16, 181-193. [CrossRef] [PubMed]

50. Vilchinsky, N.; Ginzburg, K.; Fait, K.; Foa, E.B. Cardiac-disease-induced PTSD (CDI-PTSD): A systematic review. Clin. Psychol. Rev. 2017, 55, 92-106. [CrossRef]

51. Tully, P.J.; Turnbull, D.A.; Beltrame, J.; Horowitz, J.; Cosh, S.; Baumeister, H.; Wittert, G.A. Panic disorder and incident coronary heart disease: A systematic review and meta-regression in 1,131,612 persons and 58,111 cardiac events. Psychol. Med. 2015, 45, 2909-2920. [CrossRef]

52. Valtorta, N.K.; Kanaan, M.; Gilbody, S.; Ronzi, S.; Hanratty, B. Loneliness and social isolation as risk factors for coronary heart disease and stroke: Systematic review and meta-analysis of longitudinal observational studies. Heart 2016, 102, $1009-1016$. [CrossRef]

53. Celano, C.M.; Millstein, R.A.; Bedoya, C.A.; Healy, B.C.; Roest, A.M.; Huffman, J.C. Association between anxiety and mortality in patients with coronary artery disease: A meta-analysis. Am. Heart J. 2015, 170, 1105-1115. [CrossRef]

54. Buckland, S.A.; Pozehl, B.; Yates, B. Depressive Symptoms in Women with Coronary Heart Disease. J. Cardiovasc. Nurs. 2019, 34, 52-59. [CrossRef]

55. Kendler, K.S.; Gardner, C.O.; Fiske, A.; Gatz, M. Major Depression and Coronary Artery Disease in the Swedish Twin Registry. Arch. Gen. Psychiatry 2009, 66, 857. [CrossRef]

56. Gathright, E.C.; Goldstein, C.M.; Josephson, R.A.; Hughes, J.W. Depression increases the risk of mortality in patients with heart failure: A meta-analysis. J. Psychosom. Res. 2017, 94, 82-89. [CrossRef]

57. Jonas, B.S.; Lando, J.F. Negative Affect as a Prospective Risk Factor for Hypertension. Psychosom. Med. 2000, 62, 188-196. [CrossRef]

58. Mahmood, S.; Hassan, S.Z.; Tabraze, M.; Khan, M.O.; Javed, I.; Ahmed, A.; Siddiqui, O.M.; Narmeen, M.; Ahmed, M.J.; Tariq, A.; et al. Prevalence and Predictors of Depression Amongst Hypertensive Individuals in Karachi, Pakistan. Cureus 2017, 9, e1397. [CrossRef]

59. Suzuki, S.; Kasanuki, H. The influences of psychosocial aspects and anxiety symptoms on quality of life of patients with arrhythmia: Investigation in paroxysmal atrial fibrillation. Int. J. Behav. Med. 2004, 11, 104-109. [CrossRef]

60. Sears, S.F. Quality of life and psychological functioning of ICD patients. Heart 2002, 87, 488-493. [CrossRef]

61. Addicks, S.H.; McNeil, D.W.; Randall, C.L.; Goddard, A.; Romito, L.M.; Sirbu, C.; Kaushal, G.; Metzger, A.; Weaver, B.D. Dental Care-Related Fear and Anxiety: Distress Tolerance as a Possible Mechanism. JDR Clin. Transl. Res. 2017, 2, 304-311. [CrossRef]

62. Mills, R.; McCusker, C.G.; Tennyson, C.; Hanna, D. Neuropsychological outcomes in CHD beyond childhood: A meta-analysis. Cardiol. Young 2018, 28, 421-431. [CrossRef] 
63. Luyckx, V.A.; Tonelli, M.; Stanifer, J.W. The Global Burden of Kidney Disease and the Sustainable Development Goals; Bulletin of the World Health Organization: Geneva, Switzerland, 2018; Volume 96.

64. Costantinides, F.; Castronovo, G.; Vettori, E.; Frattini, C.; Artero, M.L.; Bevilacqua, L.; Berton, F.; Nicolin, V.; Di Lenarda, R. Dental Care for Patients with End-Stage Renal Disease and Undergoing Hemodialysis. Int. J. Dent. 2018, 9610892. [CrossRef]

65. de Rossi, S.S.; Glick, M. Dental considerations for the patient with renal disease receiving hemodialysis. J. Am. Dent. Assoc. 1996 127, 211-219. [CrossRef]

66. Kim, J.C.; Kalantar-Zadeh, K.; Kopple, J.D. Frailty and Protein-Energy Wasting in Elderly Patients with End Stage Kidney Disease. J. Am. Soc. Nephrol. 2013, 24, 337-351. [CrossRef]

67. Levy, N.B. What is psychonephrology? J. Nephrol. 2008, 21 (Suppl. 1), S51-S53.

68. Ravaghi, H.; Behzadifar, M.; Behzadifar, M.; Taheri Mirghaed, M.; Aryankhesal, A.; Salemi, M.; Bragazzi, N.L. Prevalence of Depression in Hemodialysis Patients in Iran: A Systematic Review and Meta-analysis. Iran. J. Kidney Dis. 2017, 11, 90-98.

69. Muscat, P.; Chilcot, J.; Weinman, J.; Hudson, J. Exploring the relationship between illness perceptions and depression in patients with chronic kidney disease: A systematic literature review. J. Ren. Care 2018, 44, 174-185. [CrossRef]

70. Gregg, L.P.; Carmody, T.; Le, D.; Martins, G.; Trivedi, M.; Hedayati, S.S. A Systematic Review and Meta-Analysis of Depression and Protein-Energy Wasting in Kidney Disease. Kidney Int. Rep. 2020, 5, 318-330. [CrossRef] [PubMed]

71. De Pasquale, C.; Pistorio, M.L.; Veroux, M.; Indelicato, L.; Biffa, G.; Bennardi, N.; Zoncheddu, P.; Martinelli, V.; Giaquinta, A.; Veroux, P. Psychological and Psychopathological Aspects of Kidney Transplantation: A Systematic Review. Front. Psychiatry 2020, 11. [CrossRef]

72. Berger, I.; Wu, S.; Masson, P.; Kelly, P.J.; Duthie, F.A.; Whiteley, W.; Parker, D.; Gillespie, D.; Webster, A.C. Cognition in chronic kidney disease: A systematic review and meta-analysis. BMC Med. 2016, 14, 206. [CrossRef] [PubMed]

73. Shea, Y.; Lee, M.C.; Mok, M.M.; Chan, F.H.; Chan, T.M. Prevalence of cognitive impairment among peritoneal dialysis patients: A systematic review and meta-analysis. Clin. Exp. Nephrol. 2019, 23, 1221-1234. [CrossRef] [PubMed]

74. Bailey, P.K.; Hamilton, A.J.; Clissold, R.L.; Inward, C.D.; Caskey, F.J.; Ben-Shlomo, Y.; Owen-Smith, A. Young adults' perspectives on living with kidney failure: A systematic review and thematic synthesis of qualitative studies. BMJ Open 2018, 8, e019926. [CrossRef] [PubMed]

75. Sousa, H.; Ribeiro, O.; Paúl, C.; Costa, E.; Miranda, V.; Ribeiro, F.; Figueiredo, D. Social support and treatment adherence in patients with end-stage renal disease: A systematic review. Semin. Dial. 2019, 32, 562-574. [CrossRef]

76. Tanaka, M.; Yamazaki, S.; Hayashino, Y.; Fukuhara, S.; Akiba, T.; Saito, A.; Asano, Y.; Port, F.K.; Kurokawa, K.; Akizawa, T. Hypercalcaemia is associated with poor mental health in haemodialysis patients: Results from Japan DOPPS. Nephrol. Dial. Transplant. 2007, 22, 1658-1664. [CrossRef]

77. Celano, C.M.; Freudenreich, O.; Fernandez-Robles, C.; Stern, T.A.; Caro, M.A.; Huffman, J.C. Depressogenic effects of medications: A review. Dialogues Clin. Neurosci. 2011, 13, 109-125. [CrossRef]

78. Borda, M.G.; Soennesyn, H.; Steves, C.J.; Osland Vik-Mo, A.; Pérez-Zepeda, M.U.; Aarsland, D. Frailty in Older Adults with Mild Dementia: Dementia with Lewy Bodies and Alzheimer's Disease. Dement. Geriatr. Cogn. Dis. Extra 2019, 9, 176-183. [CrossRef]

79. Xiao, J.L.; Xu, G.C.; de Hoog, S.; Qiao, J.J.; Fang, H.; Li, Y.L. Oral Prevalence of Candida Species in Patients Undergoing Systemic Glucocorticoid Therapy and the Antifungal Sensitivity of the Isolates. Infect Drug Resist. 2020, 13, 2601-2607. [CrossRef]

80. Cheng, T.; Li, Y.; Zhang, H.; Chen, L.; Tu, J.; Hui, X.; Cheng, Q.; Wan, H. Incidence of oral candidiasis is associated with inhaled corticosteroids in Chinese patients: A systematic review and meta-analysis. Int. J. Clin. Exp. Med. 2017, 10, 5546-5560.

81. Nadig, S.; Ashwathappa, D.; Manjunath, M.; Krishna, S.; Annaji, A.; Shivaprakash, P. A relationship between salivary flow rates and Candida counts in patients with xerostomia. J. Oral Maxillofac. Pathol. 2017, 21, 316. [CrossRef]

82. Louati, K.; Berenbaum, F. Fatigue in chronic inflammation-A link to pain pathways. Arthritis Res. Ther. 2015, 17, 254. [CrossRef]

83. Qiu, X.; Zhang, X.; Cai, L.; Yan, C.; Yu, L.; Fan, J.; Zhang, R.; Huang, J.; Duan, X. Rheumatoid arthritis and risk of anxiety: A meta-analysis of cohort studies. Clin. Rheumatol. 2019, 38, 2053-2061. [CrossRef]

84. Basta, F.; Afeltra, A.; Margiotta, D.P.E. Fatigue in systemic sclerosis: A systematic review. Clin. Exp. Rheumatol. 2018, 36 (Suppl. 1), 150-160.

85. Primdahl, J.; Hegelund, A.; Lorenzen, A.G.; Loeppenthin, K.; Dures, E.; Appel Esbensen, B. The Experience of people with rheumatoid arthritis living with fatigue: A qualitative metasynthesis. BMJ Open 2019, 9, e024338. [CrossRef]

86. Matcham, F.; Ali, S.; Hotopf, M.; Chalder, T. Psychological correlates of fatigue in rheumatoid arthritis: A systematic review. Clin. Psychol. Rev. 2015, 39, 16-29. [CrossRef]

87. Gu, M.; Cheng, Q.; Wang, X.; Yuan, F.; Sam, N.; Pan, H.; Li, B.; Ye, D. The impact of SLE on health-related quality of life assessed with SF-36: A systemic review and meta-analysis. Lupus 2019, 28, 371-382. [CrossRef] [PubMed]

88. Al-Ezzi, M.Y.; Pathak, N.; Tappuni, A.R.; Khan, K.S. Primary Sjögren's syndrome impact on smell, taste, sexuality and quality of life in female patients: A systematic review and meta-analysis. Mod. Rheumatol. 2017, 27, 623-629. [CrossRef]

89. Smirani, R.; Truchetet, M.; Poursac, N.; Naveau, A.; Schaeverbeke, T.; Devillard, R. Impact of systemic sclerosis oral manifestations on patients' health-related quality of life: A systematic review. J. Oral Pathol. Med. 2018, 47, 808-815. [CrossRef] [PubMed]

90. Meade, T.; Manolios, N.; Cumming, S.R.; Conaghan, P.G.; Katz, P. Cognitive Impairment in Rheumatoid Arthritis: A Systematic Review. Arthritis Care Res. (Hoboken) 2018, 70, 39-52. [CrossRef] [PubMed]

91. Li, Z.; Yang, Y.; Dong, C.; Li, L.; Cui, Y.; Zhao, Q.; Gu, Z. The prevalence of suicidal ideation and suicide attempt in patients with rheumatic diseases: A systematic review and meta-analysis. Psychol. Health Med. 2018, 23, 1025-1036. [CrossRef] 
92. Nerurkar, L.; Siebert, S.; McInnes, I.B.; Cavanagh, J. Rheumatoid arthritis and depression: An inflammatory perspective. The Lancet Psychiatry 2019, 6, 164-173. [CrossRef]

93. Hanly, J.G. Diagnosis and management of neuropsychiatric SLE. Nat. Rev. Rheumatol. 2014, 10, 338-347. [CrossRef]

94. de Almeida Macêdo, E.; Appenzeller, S.; Lavras Costallat, L.T. Assessment of the Hospital Anxiety and Depression Scale (HADS) performance for the diagnosis of anxiety in patients with systemic lupus erythematosus. Rheumatol. Int. 2017, 37, 1999-2004. [CrossRef]

95. Cui, Y.; Li, L.; Yin, R.; Zhao, Q.; Chen, S.; Zhang, Q.; Shen, B. Depression in primary Sjögren's syndrome: A systematic review and meta-analysis. Psychol. Health Med. 2018, 23, 198-209. [CrossRef]

96. Chau, S.Y.; Mok, C.C. Factors predictive of corticosteroid psychosis in patients with systemic lupus erythematosus. Neurology 2003, 61, 104-107. [CrossRef]

97. Bhangle, S.D.; Kramer, N.; Rosenstein, E.D. Corticosteroid-induced neuropsychiatric disorders: Review and contrast with neuropsychiatric lupus. Rheumatol. Int. 2013, 33, 1923-1932. [CrossRef]

98. Koray, M.; Dülger, O.; Ak, G.; Horasanli, S.; Uçok, A.; Tanyeri, H.; Badur, S. The evaluation of anxiety and salivary cortisol levels in patients with oral lichen planus. Oral Dis. 2003, 9, 298-301. [CrossRef]

99. Toyofuku, A. Psychosomatic problems in dentistry. BioPsychoSocial Med. 2016, 10, 14. [CrossRef] [PubMed]

100. Rivera, C. Essentials of recurrent aphthous stomatitis. Biomed Rep. 2019, 11, 47-50. [CrossRef]

101. Reners, M.; Brecx, M. Stress and periodontal disease. Int. J. Dent. Hyg. 2007, 5, 199-204. [CrossRef] [PubMed]

102. Tikhonova, S.; Booij, L.; D'Souza, V.; Crosara, K.T.B.; Siqueira, W.L.; Emami, E. Investigating the association between stress, saliva and dental caries: A scoping review. BMC Oral Health 2018, 18, 41. [CrossRef]

103. da Silva, A.N.; de Lima, S.T.A.; Vettore, M.V. Protective psychosocial factors and dental caries in children and adolescents: A systematic review and meta-analysis. Int. J. Paediatr. Dent. 2018. [CrossRef] [PubMed]

104. Kisely, S.; Sawyer, E.; Siskind, D.; Lalloo, R. The oral health of people with anxiety and depressive disorders-A systematic review and meta-analysis. J. Affect Disord. 2016, 200, 119-132. [CrossRef] [PubMed] 